\title{
Development and cellular localization of rat testicular aromatase activity
}

\author{
F. F. G. Rommerts, F. H. de Jong, A. O. Brinkmann and \\ H. J. van der Molen \\ Department of Biochemistry (Division of Chemical Endocrinology), Medical Faculty, \\ Erasmus University, Rotterdam, The Netherlands
}

\begin{abstract}
Summary. Oestradiol secretion by isolated Leydig cells, Sertoli cells, myoid cells, germinal cells and liver cells from rats of different ages was measured by a validated radioimmunoassay technique. All cells, except germinal cells and liver cells, produced oestradiol when incubated in the presence of testosterone. Sertoli cells from 7-and 10-day-old rats and from prenatally irradiated adult rats were 7 times more active than cell preparations from 15-50-day-old rats. The oestradiol production in Sertoli cells prepared from 7-25-day-old rats could be stimulated with FSH. Oestradiol production by isolated Leydig cells from mature animals was 3-4 times greater than that with preparations from immature animals. LH had no effect on oestradiol production, but testosterone production was stimulated more than 5 -fold.

The oestradiol production by the isolated cells was affected by culture time, the presence of fetal calf serum in the culture medium and incubation temperature. During a culture period of 6 days oestradiol production by immature Sertoli cells increased more than 5 -fold and that by Leydig cells decreased to about $10 \%$.

Oestradiol levels in testes from 10-50-day-old rats were approximately $20 \%$ of those in testes from 7-day-old animals.
\end{abstract}

\section{Introduction}

The contribution of the different testicular cell types (Leydig cells, Sertoli cells, germinal cells) to the secretion of oestradiol-17 $\beta$ by the rat testis (de Jong, Hey \& van der Molen, 1973) is still unknown. Experiments with isolated immature Sertoli cells in culture (Dorrington, Fritz \& Armstrong, 1978; Rommerts, Krüger-Sewnarain, van Woerkom-Blik, Grootegoed \& van der Molen, 1978; Verhoeven, Dierickx \& de Moor, 1979) and with dissected tissue fractions (de Jong et al., 1974), have stimulated the notion that Sertoli cells are the main source of testicular oestradiol, but some investigators have been unable to confirm these results (Canick, Makris, Gunsalus \& Ryan, 1979; Steinberger, Tcholakian \& Steinberger, 1979). Aromatase activity is relatively low in Sertoli cells from rats older than 20 days (Dorrington et al., 1978) and high enzyme activities can be detected in interstitial cell fractions from adult rats after stimulation with hCG in vivo (Canick et al., 1979; Valladares \& Payne, 1979a). In immature rats < 15 days of age, an increase in the testicular oestradiol content could be obtained with FSH, but not with LH (Pomerantz, 1979), whereas in 15-day-old rats and mature rats, hCG but not FSH injections could stimulate aromatase activity (Canick et al., 1979; Valladares \& Payne, 1979a). These results suggest that the cellular distribution of aromatase activity may change during maturation of the testis. 
It has been suggested that the in-vitro oestradiol production is overestimated by radioimmunoassay (Steinberger et al., 1979). We have therefore validated our radioimmunoassay technique for oestradiol and have compared, in different incubation conditions, the capacity for oestradiol production by interstitial (Leydig) cells and cells in the seminiferous tubules obtained from maturing rats.

\section{Materials and Methods}

Mature and immature male rats (Wistar strain, substrain R-Amsterdam) were used. In some experiments female rats were irradiated at Day 19 of gestation in order to obtain germinal cell-depleted testis (Beaumont, 1960). Methods for isolation, characterization and incubation of cells have been published elsewhere for testicular and tumour Leydig cells (Rommerts, van Roemburg, Lindh, Hegge \& van der Molen, 1982), for Sertoli cells and myoid cells (Rommerts et al., 1978) and for spermatocytes and spermatids (Jutte, Grootegoed, Rommerts \& van der Molen, 1981). From the cell suspension obtained after the collagenase treatment, viable Leydig cells and other somatic cells were isolated by selective attachment to the plastic surface of the culture dish. Erythrocytes, germinal cells and broken cells present in the collagenase-treated cell preparation were easily removed, because these cells did not attach to the plastic after a preincubation period of $1 \mathrm{~h}$ in the presence of $1 \%$ fetal calf serum.

Leydig cells from adult testes were only used after sedimentation of the "collagenase cell suspension" through Ficoll, as described by Janszen, Cooke, van Driel \& van der Molen (1976). The Ficoll purification step was also used in some experiments with interstitial cells from 20 -day-old rats and resulted in two cell fractions: fraction $I$, containing $3 \beta$-hydroxysteroid dehydrogenase (HSD)-positive cells, was obtained after centrifugation for 10 min at $1500 \mathrm{~g}$ through $13 \%$ Ficoll and fraction II, containing small amounts of $3 \beta$-HSD-positive cells, was obtained after a 2 -fold dilution of the $13 \%$ Ficoll supernatant and a subsequent centrifugation for $10 \mathrm{~min}$ at $1500 \mathrm{~g}$. Germinal cells and erythrocytes in both cell fractions were removed after attachment of the somatic cells to the plastic surface during the preincubation period.

Oestradiol- $17 \beta$ was measured with a radioimmunoassay technique, as described by de Jong et al. (1973). Steroid concentrations in culture media were measured with the omission of the chromatography step. Oestradiol production by Sertoli cells was also calculated from the conversion of labelled testosterone to labelled oestradiol. Sertoli cells were incubated for $24 \mathrm{~h}$ under different conditions in $2 \mathrm{ml}$ culture medium, containing $10 \mathrm{ng}\left[7 \alpha^{-3} \mathrm{H}\right]$ testosterone (sp. act. $25 \mathrm{Ci} / \mathrm{mmol}$ ) (New England Nuclear, Boston, Massachusetts, U.S.A.) per ml. At the end of the incubation period appropriate amounts of ${ }^{14} \mathrm{C}$-labelled oestradiol were added to the culture medium. The steroids were extracted with ethyl acetate and an oestradiol fraction was isolated after chromatography on Sephadex $\mathrm{LH}-20$, as described for the radioimmunoassay procedure. After addition of crystalline oestradiol-17ß, crystallizations were carried out in ethanol/water $(1: 1 \mathrm{v} / \mathrm{v})$, methanol/water $(1: 1 \mathrm{v} / \mathrm{v})$ and dioxane/water $(1: 1 \mathrm{v} / \mathrm{v})$ mixtures until constant ${ }^{3} \mathrm{H} /{ }^{14} \mathrm{C}$-ratios in crystals and mother liquor were obtained.

\section{Results}

\section{Validation of the radioimmunoassay technique}

Sertoli cells from 22-day-old rats were preincubated for 4 days from Day 0 until Day 4 in the presence of testosterone at 32 or at $37^{\circ} \mathrm{C}$ and with or without $\mathrm{FSH}$, and measurements were carried out at Days 4, 5 and 6. During Days 4 and 6 oestradiol production from different amounts of added testosterone was estimated in culture medium by radioimmunoassay. For validation of the radioimmunoassay, the oestradiol production was also measured from 
tritium-labelled testosterone at Day 5 after crystallization to constant specific activity of the oestradiol fraction. It was found that the oestradiol concentrations after crystallization were 105 $\pm 24 \%$ (mean \pm s.e.m., $n=8$ ) of those measured by radioimmunoassay over a range of 6 to $1000 \mathrm{pg}$ oestradiol.

\section{Oestradiol production by Leydig cells and other cells}

No oestradiol could be detected in culture media from liver cells and germinal cells. Pure myoid cells showed a low secretion of oestradiol $\left(0.16 \pm 0.04 \mathrm{ng} / \mathrm{mg}\right.$ protein $\cdot 24 \mathrm{~h}^{-1} ;$ mean \pm s.e.m., $n=7$ ). Interstitial cells were more active in oestradiol production, especially those obtained from tumour tissue of mature testes (Table 1), which also contained a higher percentage of Leydig cells.

Table 1. Oestradiol secretion by Leydig cells isolated from immature and mature rats

\begin{tabular}{lcc}
\hline $\begin{array}{c}\text { Age of rat } \\
\text { (days) }\end{array}$ & $\begin{array}{c}\% \\
\text { Leydig cells }\end{array}$ & $\begin{array}{c}\text { Oestradiol production } \\
\text { (ng/mg protein } \cdot 24 \mathrm{~h}^{-1} \text { ) }\end{array}$ \\
\hline 7 & $10-30$ & $0.33 \pm 0.07(4)$ \\
20 & $10-30$ & $0.45 \pm 0.07(8)$ \\
70 & $40-60$ & $1.5 \pm 0.33(9)$ \\
(normal) & $40-60$ & $2.9 \pm 0.41(5)$ \\
70 & 100 & $2.1 \pm 0.21(8)$ \\
$\begin{array}{l}\text { (irradiated) } \\
70-100\end{array}$ & & \\
(tumour cells) & & \\
\hline
\end{tabular}

Leydig cells were incubated for $24 \mathrm{~h}$ at $37^{\circ} \mathrm{C}$ in the presence of $1 \%$ fetal calf serum, LH $(100 \mathrm{ng} / \mathrm{ml})$, FSH $(1 \mu \mathrm{g} / \mathrm{ml})$ and testosterone $(200 \mathrm{ng} / \mathrm{ml})$. The number of Leydig cells in the interstitial cell preparations was assessed by determination of the percentage of $3 \beta$-hydroxysteroid dehydrogenase-positive cells. Values are mean \pm s.e.m. for the no. of observations indicated in parentheses, obtained with at least two different cell preparations.

Some interstitial cell fractions from 20-day-old rats produced much less pregnenolone or testosterone than enriched Leydig cell preparations, but produced similar amounts of oestradiol (Table 2). Stimulation of oestradiol production by $\mathbf{L H}$ was never observed, whereas the production of pregnenolone or testosterone in all Leydig cell preparations could be stimulated by LH more than 5-fold.

Table 2. Steroid production by different cell fractions obtained from 20-day-old rats

\begin{tabular}{|c|c|c|c|c|}
\hline $\begin{array}{l}\text { Cell } \\
\text { preparation* }\end{array}$ & $\begin{array}{c}\text { LH } \\
(100 \mathrm{ng} / \mathrm{ml})\end{array}$ & $\begin{array}{c}\text { Pregnenolone } \\
\text { (ng/mg protein } 2 \mathrm{~h}^{-1} \text { ) }\end{array}$ & $\begin{array}{c}\text { Testosterone } \\
\text { (ng/mg protein } 2 \mathrm{~h}^{-1}\end{array}$ & $\begin{array}{c}\text { Oestradiol } \\
\left(\mathrm{ng} / \mathrm{mg} \text { protein } 24 \mathrm{~h}^{-1}\right)\end{array}$ \\
\hline $\begin{array}{l}\text { Fraction I } \\
\quad \text { (enriched Leydig cells) }\end{array}$ & $\begin{array}{l}- \\
+\end{array}$ & $\begin{array}{rrr}50 & \pm 35 & (6) \\
730 & \pm 390 & (6)\end{array}$ & $\begin{array}{r}9 ; 16 \\
140 ; 143\end{array}$ & $\begin{array}{l}0.17 \pm 0.14 \quad(6) \\
0.32 \pm 0.18 \text { (6) }\end{array}$ \\
\hline Fraction II & - & 13 & $0.5 ; \quad 2$ & $0.15 ; 0.27$ \\
\hline (interstitial cells) & + & 212 & $9 ; 15$ & $0.23 ; 0.29$ \\
\hline \multirow[t]{2}{*}{ Sertoli cells } & - & $0.4(3)$ & - & $0.41 \pm 0.21 \dagger(8)$ \\
\hline & + & $1 \cdot 1(3)$ & - & \\
\hline
\end{tabular}

Values are mean \pm s.d. for the no. of observations in parentheses.

* See 'Materials and Methods'.

† In the presence of FSH $(1 \mu \mathrm{g} / \mathrm{ml})$ and testosterone $(200 \mathrm{ng} / \mathrm{ml})$. 
Oestradiol production by Sertoli cells

Cell preparations from 7- or 10-day-old rats were much more active than preparations from more mature rats (Text-fig. 1). Since the percentage of Sertoli cells $(>80 \%)$ was similar in rats aged 7,10 and 15 days, the low oestradiol secretion by 15 -day-old rats must reflect a decrease in the activity of the Sertoli cells.

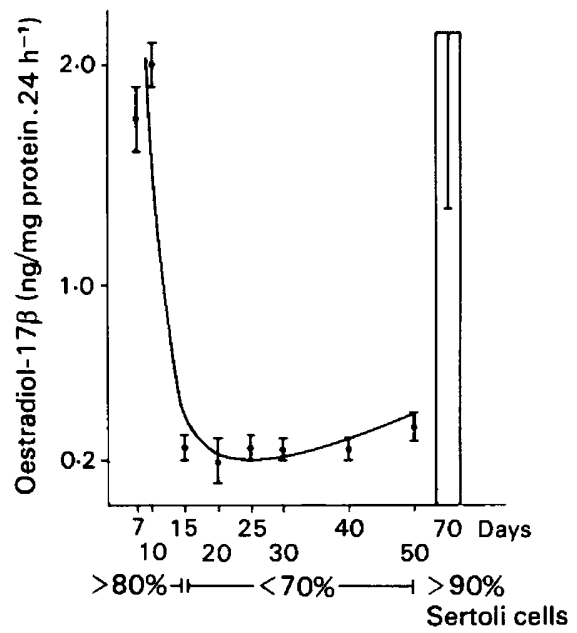

Text-fig. 1. Oestradiol secretion by Sertoli cell fractions obtained from rats of different ages. For incubation conditions, see Table 1 . Values are mean \pm s.d. for at least 4 observations. The 70-day-old rats had been irradiated prenatally.

There was high aromatase activity in Sertoli cell preparations from the prenatally irradiated animals (Text-fig. 1). The oestradiol production was FSH-dependent in cell preparations from rats up to 25 days of age (data not shown). In cell preparations from older animals no significant stimulation by FSH could be detected.

\section{Concentrations of oestradiol in testis and plasma}

The testicular concentrations of oestradiol were not significantly different from Day 10 to Day 50, but the value at Day 7 was about 5 times higher than at all other times studied (Text-fig. 2). Peripheral plasma oestradiol concentrations were $10-20 \mathrm{pg} / \mathrm{ml}$ and there were no significant differences between age groups.

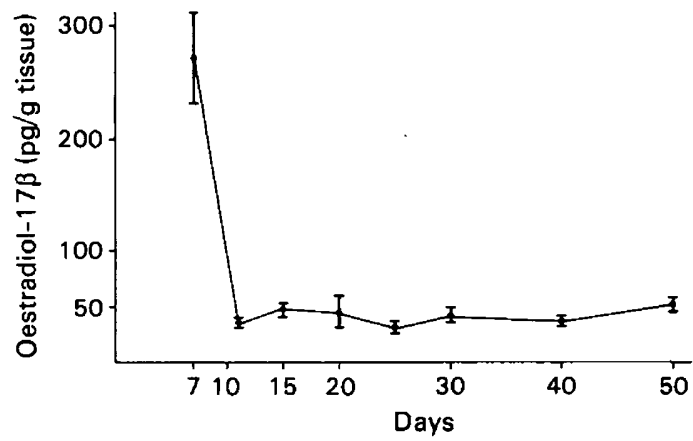

Text-fig. 2. Effect of age on oestradiol concentrations in rat testicular tissue. Values are mean \pm s.e.m. for 3-4 estimations. 


\section{Effect of culture time on oestradiol production}

Oestradiol secretion by Sertoli cells and Leydig cells was measured on the day of the cell preparation (Day 0 ) and on the 6th day (Day 5) of the culture period. Sertoli cells incubated with FSH and testosterone at $37^{\circ} \mathrm{C}$ became more active during this culture period (Table 3). The activities did not change after culture periods of 5-10 days. Cells incubated with FSH and testosterone at $37^{\circ} \mathrm{C}$ were more active than those at $32^{\circ} \mathrm{C}$. Sertoli cells incubated with $1 \%$ fetal calf serum only were less active at Day 5 than at Day 0 . Leydig cells from tumour or testis tissue showed a decrease to $10 \%$ in the $24 \mathrm{~h}$ oestradiol secretion after a 6-day culture period (Table 3). Part of this decrease may have been caused by an approximately 4 -fold increase in the protein content of the dishes during the culture period.

Table 3. Effect of culture time on oestradiol secretion by Sertoli cells (from 21-day-old rats) and Leydig cells

\begin{tabular}{|c|c|c|c|c|}
\hline \multicolumn{2}{|c|}{ Culture conditions } & \multicolumn{2}{|c|}{ Oestradiol $\left(\mathrm{pg} / \mathrm{mg}\right.$ protein $\left.\cdot 24 \mathrm{~h}^{-1}\right)$} & \multirow[b]{2}{*}{$\frac{\mathrm{B}}{\mathrm{A}}$} \\
\hline Addition & $\begin{array}{l}\text { Temp. } \\
\left({ }^{\circ} \mathrm{C}\right)\end{array}$ & $\begin{array}{c}\text { Day } 0 \\
\text { (A) }\end{array}$ & $\begin{array}{c}\text { Day } 5 \\
\text { (B) }\end{array}$ & \\
\hline \multicolumn{5}{|l|}{ Sertoli cells } \\
\hline $1 \%$ FCS & 32 & $226+91(5)$ & $102 \pm 29(12)^{*}$ & 0.5 \\
\hline $\mathrm{FSH}+\mathrm{T}$ & 32 & $62 \pm 15(8)$ & $315 \pm 210(15)$ & $5 \cdot 1$ \\
\hline $\mathrm{FSH}+\mathrm{T}$ & 37 & $124 \pm 35(6)$ & $2480+830(8)^{*}$ & 20 \\
\hline $\mathrm{FSH}+\mathrm{T}+1 \% \mathrm{FCS}$ & 37 & $202 \pm 108(7)$ & $886 \pm 100(4)^{*}$ & $4 \cdot 4$ \\
\hline \multicolumn{5}{|l|}{ Leydig cells } \\
\hline \multicolumn{5}{|l|}{ From tumour } \\
\hline $1 \% \mathrm{FCS}+\mathrm{LH}+\mathrm{T}$ & 37 & $13000 ; 11000$ & $1700: 1200$ & $0 \cdot 1$ \\
\hline From testis & & & & \\
\hline $1 \% \mathrm{FCS}+\mathrm{LH}+\mathrm{T}$ & 37 & $3000 \pm 1100(4)$ & $215 \pm 41(4)^{*}$ & $0 \cdot 1$ \\
\hline
\end{tabular}

Culture medium was collected after $24 \mathrm{~h}$ and new medium was added. The cells were subsequently incubated for 5 days. Fresh medium was added at the beginning of the 6 th day and the media were collected for oestradiol measurements after $24 \mathrm{~h} .1 \% \mathrm{FCS}=$ fetal calf serum: $\mathrm{FSH}=2 \mu \mathrm{g} / \mathrm{ml} ; \mathrm{LH}=1 \mu \mathrm{g} / \mathrm{ml}: \mathrm{T}=$ testosterone. $200 \mathrm{ng} / \mathrm{ml}$.

Values are mean \pm s.d. for the no. of observations in parentheses, with at least three different cell preparations.

* $P<0.01$ when compared to Day 0 (independent Student's $t$ test).

Table 4. Effect of $1 \%$ fetal calf serum (FCS) on oestradiol production during the first $24 \mathrm{~h}$ by Sertoli cells from rats of different ages and by tumour Leydig cells

\begin{tabular}{|c|c|c|c|c|}
\hline \multirow[b]{2}{*}{ Cell type } & \multirow{2}{*}{$\begin{array}{l}\text { Culture } \\
\text { conditions } \\
\left(37^{\circ} \mathrm{C}\right)\end{array}$} & \multicolumn{2}{|c|}{ Oestradiol (pg/mg protein $\cdot 24 \mathrm{~h}^{-1}$ ) } & \multirow[b]{2}{*}{$\frac{B}{A}$} \\
\hline & & $\begin{array}{l}\text { Without FCS } \\
\text { (A) }\end{array}$ & $\begin{array}{l}\text { With } 1 \% \text { FCS } \\
\text { (B) }\end{array}$ & \\
\hline \multicolumn{5}{|l|}{ Sertoli cells } \\
\hline $7-10$ days & $\mathrm{FSH}+\mathrm{T}$ & $3600 \pm 3700(7)$ & $2000+800(8)$ & 0.5 \\
\hline 20 days & FSH $+\mathrm{T}$ & $93 \pm 80(6)$ & $202 \pm 108(7)$ & 2 \\
\hline $\begin{array}{l}70 \text { days } \\
\text { (prenatally irradiated) }\end{array}$ & $\mathrm{FSH}+\mathrm{T}$ & $415 \pm 180(5)$ & $1930 \pm 780(5)^{*}$ & $4 \cdot 7$ \\
\hline Tumour Leydig cells & FSH $+\mathbf{L H}$ & $\begin{array}{r}\text { 2095: } 1500 \\
10000 ; 11000\end{array}$ & $\begin{array}{rr}1320: & 1550 \\
13600: 11 & 100\end{array}$ & 0.9 \\
\hline
\end{tabular}

Values are mean \pm s.d. for the no. of observations in parentheses obtained with at least 3 different cell preparations. $\mathrm{FSH}=2 \mu \mathrm{g} / \mathrm{ml} ; \mathrm{T}=200 \mathrm{ng}$ testosterone $/ \mathrm{ml} ; \mathrm{LH}=1 \mu \mathrm{g} / \mathrm{ml}$.

${ }^{*} P<0.01$ when compared to incubation condition without FCS (independent Student's $t$ test). 


\section{Effects of fetal calf serum on oestradiol production}

Fetal calf serum had no significant effect on oestradiol production by tumour Leydig cells and immature Sertoli cells. However, oestradiol production by Sertoli cells from mature, prenatally irradiated rats was significantly stimulated (Table 4 ).

\section{Discussion}

Interstitial cells, Sertoli cells and myoid cells, but not germinal cells and liver cells, produced oestradiol from added testosterone. The biosynthetic activities of the isolated Sertoli cells and interstitial cells depend on the culture conditions.

Oestradiol production by immature Sertoli cells increased during the culture period, whereas Leydig cells secreted less oestradiol after a 6-day culture period. Secretion of oestradiol by mature Sertoli cells could be stimulated by serum additions to the culture medium, but no effects could be demonstrated when tumour Leydig cells were used. Inhibitory effects of serum on the induction of aromatase activity have been observed after culturing immature Sertoli cells from 21-day-old rats for $>5$ days at $37^{\circ} \mathrm{C}$ (Table 3). Isolated Sertoli cells and Leydig cells, when kept in culture, may thus progressively lose or acquire specific biochemical activities and this could indicate some kind of a de-differentiation process.

The different effects of fetal calf serum in the culture medium on oestradiol production raise the question whether fetal calf serum should be used at all. On the other hand, cells in vivo are exposed to body fluids which contain many serum constituents and it has been shown that cells in vitro require serum additions for growth. However, serum may also inhibit FSH-dependent steroidogenesis in granulosa cells (Orly, Sato \& Erickson, 1980). It therefore seems essential to establish culture or incubation conditions under which freshly isolated Leydig cells and Sertoli cells keep their in-vivo properties, at least during the time required for the investigations.

The results with enriched Leydig cell fractions and cell fractions containing viable cells, but with relatively low amounts of Leydig cells, demonstrated that interstitial cells other than Leydig cells contribute to the oestradiol production with a specific activity similar to that of Leydig cells. Thus, the oestradiol production per $\mathrm{mg}$ protein in interstitial cell preparations from testes of 20-day-old rats is independent of the percentage of Leydig cells. Hence, the higher oestradiol production by Leydig cell preparations from more mature animals probably reflects a true increase in the activity per Leydig cell. LH had no effect on oestradiol production over $24 \mathrm{~h}$ by isolated Leydig cells, but testosterone or pregnenolone production during $2 \mathrm{~h}$ was stimulated more than 5-fold in all Leydig cell preparations (Table 2). The maximal oestradiol production by Leydig cells from adult rats was $<0.02 \%$ of the testosterone production. A reduced activity of the microsomal $17 \alpha$-hydroxylase activity was observed after $4 \mathrm{~h}$ incubation of tumour Leydig cells (Rommerts et al., 1982). Similar changes in vitro may also occur in enzymes involved in the aromatization of androgens. However, the production rate of oestradiol by tumour cells in the first $8 \mathrm{~h}$ was not different from that during the next period of $16 \mathrm{~h}$. In contrast to these results, LH has been reported to stimulate aromatization of added $\left[{ }^{3} \mathrm{H}\right]$ testosterone in isolated Leydig cells from mature rat testes, with maximal oestradiol production being about $2 \%$ of the testosterone production (Valladares \& Payne, 1979b). The discrepancy with the present results cannot be explained.

Aggregates containing Sertoli cells which were prepared from 7- or 10-day-old animals and incubated with FSH, LH and testosterone were approximately 7 times more active than preparations from more mature animals. The low, but rather constant oestradiol production in the tubular preparations may indicate the appearance of more active Sertoli cells, because the Sertoli cell content in these preparations becomes progressively lower, due to increased numbers of germinal cells without aromatase activity. This appears to be supported by the relatively high activity of oestradiol production in pure Sertoli cell preparations isolated from testes of 
70-day-old-rats which were prenatally irradiated. However, the development of these Sertoli cells might have been influenced by the irradiation. A decrease in aromatase activity in isolated Sertoli cells obtained from 5-30-day-old rats has also been reported by Dorrington et al. (1978), but these authors did not investigate cell preparations from more mature animals and did not use $1 \%$ fetal calf serum in the culture medium. However, since fetal calf serum may stimulate oestradiol production (Rommerts, Krüger-Sewnarain, Grootegoed, de Jong \& van der Molen, 1979), the results of Dorrington et al. (1978) may have underestimated the cellular capacity for oestradiol production. In the present study oestradiol production in vitro by trophic hormones was only possible with immature Sertoli cells isolated from rats aged $\leqslant 25$ days. An age-dependent response to FSH in isolated Sertoli cells was also observed by Steinberger, Hinta \& Heindel (1978), who found that the FSH-dependent cAMP production in isolated Sertoli cells decreased to $<25 \%$ when cell preparations from 24 -day-old rats were compared with preparations from 18-day-old animals.

Our observations on the predominant activity of aromatase activity in Sertoli cells of immature rats and the increase of oestradiol secretion by Leydig cells during development are in agreement with the results of Pomerantz (1979), who showed that the testicular oestradiol level in immature rats can be stimulated by FSH and not by LH. In rats older than 15 days LH appears to be more potent than FSH in the regulation of testicular oestradiol levels (de Jong et al., 1974; Canick et al., 1979).

The capacity of the Leydig cells to synthesize oestradiol suggests that the Sertoli cells are not obligatory for the regulation of oestradiol-dependent reactions in Leydig cells in adult rats. In the immature rat, however, testicular oestradiol production appears to be mainly dependent on the FSH-dependent aromatase present in the Sertoli cells.

\section{References}

Beaumont, H.M. (1960) Changes in the radio sensitivity of the testis during foetal development. Int. J. Radiat. Biol. 2, 247-256.

Canick, J.A., Makris, A., Gunsalus, G.L. \& Ryan, K.J. (1979) Testicular aromatization in immature rats: localization and stimulation after gonadotropin administration in vivo. Endocrinology 104, 285289.

de Jong, F.H., Hey, A.H. \& van der Molen, H.J. (1973) Effect of gonadotrophins on the secretion of oestradiol-17 $\beta$ and testosterone by the rat testis. $J$. Endocr. 57, 277-284.

de Jong, F.H., Hey, A.H. \& van der Molen, HJ. (1974) Oestradiol-17 $\beta$ and testosterone in rat testis tissue: effect of gonadotrophins, localization and production in vitro. J. Endocr. 60, 409-419.

Dorrington, J.H., Fritz, I.B. \& Armstrong, D.T. (1978) Control of testicular estrogen synthesis. Biol. Reprod. 18, 55-64.

Janszen, F.H.A., Cooke, B.A., van Driel, M.J.A. \& van der Molen, H.J. (1976) Purification and characterization of Leydig cells from rat testes. $J$. Endocr. 70, 345-359.

Jutte, N.H.P.M., Grootegoed, J.A., Rommerts, F.F.G. \& van der Molen, H.J. (1981) Exogenous lactate is essential for metabolic activities in isolated spermatocytes and spermatids. J. Reprod. Fert. 62, $399-405$.

Pomerantz, D.K. (1979) Effects of in-vivo gonadotropin treatment on estrogen levels in the testis of the immature rat. Biol. Reprod. 21, 1247-1255.
Oriy, J., Sato, G. \& Erickson, G.F. (1980) Serum suppresses the expression of hormonally induced functions in culture granulosa cells. Cell 20, 817827.

Rommerts, F.F.G., Krüger-Sewnarain, B.Ch., van Woerkom-Blik, A., Grootegoed, J.A. \& van der Molen, H.J. (1978) Secretion of proteins by Sertoli cell enriched cultures: effects of follicle stimulating hormone, dibutyryl cAMP and testosterone and correlation with secretion of oestradiol and androgen binding protein. Molec. cell. Endocr. 10, 39-55.

Rommerts, F.F.G., Krüger-Sewnarain, B.Ch., Grootegoed, J.A., de Jong, F.H. \& van der Molen, H.J. (1979) Secretion of proteins, androgen binding protein and oestradiol by Sertoli cells in culture: effects of serum. Acta endocr., Copenh. 90. 552-561.

Rommerts, F.F.G., van Roemburg, M.J.A., Lindh, L.M., Hegge, J.A.J. \& van der Molen, H.J. (1982) The effects of short-term culture and perifusion on LH-dependent steroid production in isolated rat Leydig cells. J. Reprod. Fert. 65, 289-297.

Steinberger, A., Hinta, M. \& Heindel, J.J. (1978) Changes in cyclic AMP responses to FSH in isolated rat Sertoli cells during sexual maturation. Biol. Reprod. 19, 566-572.

Steinberger, E., Tcholakian, R.K. \& Steinberger, A. (1979) Steroidogenesis in testicular cells. J. Steroid Biochem. 11, 185-192.

Valladares, L.E. \& Payne, A.H. (1979a) Induction of testicular aromatization by luteinizing hormone in mature rats. Endocrinology 105, 431-437. 
Valladares, L.E. \& Payne, A.H. (1979b) Acute stimulation of aromatization in Leydig cells by human chorionic gonadotropin in vitro. Proc. natn. Acad. Sci. U.S.A. 76, 4460-4463.
Verhoeven, G., Dierickx, P. \& de Moor, P. (1979)

Stimulation effect of neurotransmitters on the aromatization of testosterone by Sertoli cell-enriched cultures. Molec. cell. Endocr. 13, 241-255.

Received 23 June 1981 